\title{
Hubungan Jenis Kelamin, Usia Gestasi, dan Berat Badan Lahir dengan Sindrom Rubela Kongenital
}

\author{
Lily Cahyani Tandililing, Djatnika Setiabudi, Nelly Amalia Risan \\ Departemen Ilmu Kesehatan Anak Fakultas Kedokteran Universitas Padjadjaran/Rumah Sakit Hasan Sadikin, Bandung
}

Latar belakang. Sindrom rubela kongenital (SRK) masih merupakan masalah kesehatan di Indonesia. Berdasarkan penelitian terdahulu. faktor usia gestasi, berat badan lahir, dan jenis kelamin berhubungan dengan kasus confirmed sindrom rubela kongenital.

Tujuan. Menentukan hubungan jenis kelamin, usia gestasi, dan berat badan lahir dengan kasus probable SRK.

Metode. Penelitian observasional analitik dengan rancangan potong lintang. Data retrospektif diperoleh dari rekam medis pasien rawat inap dan rawat jalan usia $<1$ tahun periode 1 Januari 2008-31 Desember 2014, dengan kode diagnosis (ICD-10) meliputi congenital rubella syndrome, congenital heart disease, congenital cataract, sensorineural hearing loss, cerebral palsy, dan neonatal jaundice. Klasifikasi kasus SRK berdasarkan CDC 2009, yaitu suspected, probable, confirmed, dan infection only. Pemilihan subjek secara purposive sampling. Analisis statistik dilakukan dengan analisis bivariat dan regresi logistik untuk faktor dengan $p<0,25$ dengan Rasio Odds (RO) dan Interval Kepercayaan (IK) 95\%.

Hasil. Didapat 133 subjek klasifikasi SRK suspected (96), terdiri atas probable (29) dan confirmed (8). Mayoritas subjek laki-laki $(58,6 \%)$, usia ibu $25-29(48,9 \%)$ tahun, multipara $(54,1 \%)$, dan tanpa riwayat vaksinasi rubela $(100 \%)$. Hubungan bermakna didapatkan dalam analisis regresi logistik pada faktor jenis kelamin ( $\mathrm{p}=0,002$; OR 6,656; IK95\% 2,046-21,657) dan berat badan lahir (p<0,001; OR 10,365; IK95\% 2,839-37,834).

Kesimpulan. Jenis kelamin dan berat badan lahir berhubungan dengan kasus probable SRK. Diperlukan penelitian prospektif untuk menentukan hubungan usia gestasi dengan kasus probable SRK. Sari Pediatri 2015;17(4):302-6.

Kata kunci: berat badan lahir, jenis kelamin, sindrom rubela kongenital, usia gestasi

\section{Relationship of Sex, Gestational Age, and Birthweight with Congenital Rubella Syndrome}

\author{
Lily Cahyani Tandililing, Djatnika Setiabudi, Nelly Amalia Risan
}

Background. Congenital rubella syndrome (CRS) is still a public health problem in Indonesia, with the major clinical manifestations are congenital defect of heart, hearing and eyes problems. Sex, birthweight, and gestational age were have relationship with confirmed CRS cases, based on prior studies.

Objective. To determine the relationship of sex, gestational age, and birthweight with probable CRS cases.

Method. A cross-sectional study on patient aged less than 1 year old, diagnosed with congenital rubella syndrome(ICD-10), or congenital heart disease, or congenital cataract, or sensorineural hearing loss, or cerebral palsy, and patologic neonatal jaundice. Data were retrospectively evaluated from medical record of outpatients and inpatients,,from 1 January $2008-31$ Desember 2014 at Dr. Hasan Sadikin Hospital, Bandung. This study performed as a continuation of previous study with the title of "Prevalensi Sindrom Rubela Kongenital di RSUP Dr. Hasan Sadikin Bandung, 1 Januari 2008-31 Desember 2012". Variable with p $<0.25$ in bivariate analysis proceeded with multivariate analysis using odds ratio (OR) and confidence interval $95 \%(95 \% \mathrm{CI})$.

Results. Out of 133 subject, 96 suspected, 29 probable and 8 confirmed CRS cases were included in the study. Sex ( $p=0,002 ;$ OR 6,656; 95\% CI 2,046-21,657) and birthweight ( $<<0,001$; OR 10,365; 95\% CI 2,839-37,834) have relationship with probable CRS. The median for the birthweight of probable CRS was $2500 \mathrm{~g}$.

Conclusion. Sex and birthweight has relationship with probable CRS. Prospective study is needeed to determine the relationship of gestational age and probable CRS case. Sari Pediatri 2015;17(4):302-6.

Keywords: birthweight, congenital rubella syndrome, gestational age, sex

Alamat korespondensi: Dr. Lily Cahyani Tandililing. Departemen IKA FK UNPAD/RS Dr. Hasan Sadikin. Jl. Pasteur No.38 Bandung 40163. Tel. +62-22-3035957. E-mail: lily_cahyani@yahoo.com 
Rubela masih merupakan patogen yang dianggap penting di seluruh dunia, perkiraan jumlah sekitar 100.000 kasus sindrom rubela kongenital (SRK) yang terjadi setiap tahunnya. ${ }^{1,2}$ Hingga kini, Indonesia belum memiliki data mengenai prevalensi infeksi rubela akibat studi tentang kejadian rubela masih sedikit. Telah dilakukan pilot project penelitian surveilans SRK di Indonesia pada tahun 2013 dengan hasil kasus confirmed SRK 7 kasus di Bandung dan 36 di Yogyakarta. ${ }^{3}$ Pada tahun pertama kehidupan anak SRK tingkat mortalitas tinggi dengan angka kematian $10 \%$. Selain malformasi organ yang menyertai SRK, sekitar 10\%-20\% anak mengalami disabilitas mental sebagai manifestasi neurologis lanjut., ${ }^{4,5}$

Terdapat empat kriteria diagnosis yang dikeluarkan oleh Council of state and territorial epidemiologists (CSTE) CDC tahun 2009 untuk sindrom rubela kongenital, yaitu suspected, probable, confirmed, dan infection only. ${ }^{6}$ Penelitian terdahulu menyatakan hubungan jenis kelamin ${ }^{7}$ dan berat badan lahir ${ }^{8}$ dengan sindrom rubela kongenital. Kedua penelitian tersebut meneliti subjek kasus confirmed. Belum ada penelitian mengenai hubungan usia gestasi dengan sindrom rubela kongenital, tetapi bayi lahir kurang bulan merupakan manifestasi SRK yang sering ditemui. $\mathrm{Hal}$ ini disebabkan oleh disfungsi plasenta akibat kondisi patologis plasenta oleh infeksi virus rubela.$^{9,10}$

Negara berkembang seperti Indonesia belum rutin melakukan pemeriksaan serologis untuk penegakan kasus SRK sehingga manifestasi klinis merupakan acuan standar yang rutin dilakukan. Tujuan penelitian ini adalah menentukan hubungan hubungan jenis kelamin, usia gestasi dan berat badan lahir dengan kasus probable SRK yang merupakan klasifikasi berdasarkan manifestasi klinis atau secara klinis terkonfirmasi SRK.

\section{Metode}

Penelitian dilakukan di Departemen/SMF Ilmu Kesehatan Anak Rumah Sakit Dr. Hasan Sadikin Bandung pada bulan Mei 2015-Juli 2015. Subjek penelitian adalah semua pasien anak usia di bawah 1 tahun yang dirawat inap atau rawat jalan di Departemen Ilmu Kesehatan Anak (IKA) dan THTKL (Ilmu penyakit Telinga, Hidung dan Tenggorokan - Kepala dan Leher) RSUP Dr. Hasan Sadikin Bandung, dalam periode Januari 2008-Desember
2014. Penelitian ini merupakan lanjutan penelitian yang berjudul "Prevalensi Sindrom Rubela Kongenital di RSUP Dr. Hasan Sadikin Bandung, 1 Januari 200831 Desember 2012." Sebagian data penelitian diambil dari data penelitian tersebut, yaitu subjek dengan usia $<1$ tahun selanjutnya menambahkan data pasien dari rekam medik tahun 2013-2014 sesuai kriteria inklusi. Pengambilan data dari rekam medis setelah mendapatkan persetujuan penelitian dari Komite Etik Penelitian Rumah Sakit Hasan Sadikin Bandung. Data yang diambil adalah tahun kelahiran anak, manifestasi klinis, jenis kelamin, berat badan lahir, usia gestasi, hasil pemeriksaan serologis rubela, usia ibu, paritas $\mathrm{ibu}$, dan riwayat vaksinasi rubela.

Kriteria inklusi adalah anak usia $<1$ tahun yang memiliki manifestasi klinis sesuai kriteria kasus suspected atau probable SRK berdasarkan klasifikasi CDC 2009. Dalam hal ini dilakukan telaah awal melalui rekam medik dengan kode diagnosis akhir (ICD-10) meliputi congenital rubella syndrome (P35.0), congenital heart disease (Q20-Q28.9), congenital cataract ( Q12.0), sensorineural hearing Loss (H90-H90.9), cerebral palsy (G80-G80.9), dan neonatal jaundice (P59.2) yang merupakan jaundice patologis. Kriteria eksklusi adalah pasien dengan kelainan bawaan yang tidak khas pada SRK, tetapi khas pada infeksi kongenital lain, misalnya lesi kulit vesikular dan lesi ulseratif di mulut (herpes simpleks); kalsifikasi periventrikular (sitomegalovirus); kalsifikasi intrakranial, korioretinitis dan hidrosefalus (toksoplasma), serta pasien yang rekam medisnya hilang atau tidak lengkap. Usia gestasi dinyatakan dalam cukup bulan atau kurang bulan, sedangkan berat badan lahir ditentukan dalam gram. Kriteria kasus suspected SRK, yaitu memiliki setidaknya 1 manifestasi klinis mayor/minor, sedangkan kriteria kasus probable SRK, yaitu memiliki setidaknya 2 manifestasi klinis mayor atau setidaknya terdapat 1 manifestasi mayor dan 1 manifestasi minor (CDC 2009). Penelitian ini berupa observasional analitik rancangan potong lintang. Pemilihan sampel dilakukan secara purposive sampling. Perhitungan sampel ditentukan berdasarkan rumus Rule of thumb dengan jumlah minimum sampel 50. Analisis statistik pada tahap pertama menggunakan analisis bivariat. Pada hasil analisis bivariat dengan $\mathrm{p}<0,25$ dilanjutkan dengan analisis multivariat regresi logistik.

Hubungan variabel jenis kelamin dan usia gestasi (data kategorik) dengan kasus probable SRK dianalisis dengan chi-square atau uji Eksak Fisher untuk jumlah sel $<5$. Untuk variabel berat badan lahir (numerik) 
digunakan uji Mann-Whitney. Setiap variabel yang berhubungan dengan probable SRK dinyatakan sebagai rasio Odd (RO) dengan interval kepercayaan 95\%.

\section{Hasil}

Terdapat 133 kasus SRK, klasifikasi kasus terdiri atas 96 subjek suspected, 29 probable, dan 8 confirmed SRK. Tujuh puluh delapan subjek adalah laki-laki dan

Tabel 1. Karakteristik ibu dan bayi

\begin{tabular}{|c|c|c|}
\hline Karakteristik & $\begin{array}{l}\text { Jumlah } \\
(\mathrm{n}=133)\end{array}$ & $\begin{array}{c}\text { Persentase } \\
(\%)\end{array}$ \\
\hline \multicolumn{3}{|l|}{ Tahun kelahiran } \\
\hline 2007 & 3 & 2,3 \\
\hline 2008 & 4 & 3,0 \\
\hline 2009 & 5 & 3,8 \\
\hline 2010 & 17 & 12,8 \\
\hline 2011 & 35 & 26,3 \\
\hline 2012 & 52 & 39,1 \\
\hline 2013 & 12 & 9,0 \\
\hline 2014 & 5 & 3,8 \\
\hline \multicolumn{3}{|l|}{ Klasifikasi kasus } \\
\hline Suspected & 96 & 72,2 \\
\hline Probable & 29 & 21,8 \\
\hline Confirmed & 8 & 6,0 \\
\hline \multicolumn{3}{|l|}{ Jenis kelamin } \\
\hline Laki-laki & 78 & 58,6 \\
\hline Perempuan & 55 & 41,4 \\
\hline \multicolumn{3}{|l|}{ Usia gestasi } \\
\hline Kurang bulan & 77 & 57,9 \\
\hline Cukup bulan & 56 & 42,1 \\
\hline \multicolumn{3}{|l|}{ Usia ibu (tahun) } \\
\hline $15-19$ & 10 & 8,0 \\
\hline $20-24$ & 47 & 37,6 \\
\hline $25-29$ & 59 & 47,2 \\
\hline $30-39$ & 9 & 7,2 \\
\hline \multicolumn{3}{|l|}{ Paritas $(\mathrm{P})$} \\
\hline $\mathrm{P}=1$ & 61 & 48,8 \\
\hline $\mathrm{P}>1$ & 64 & 51,2 \\
\hline \multicolumn{3}{|c|}{ Riwayat vaksinasi rubela (ibu) } \\
\hline Ada & 0 & 0 \\
\hline Tidak ada & 125 & 100 \\
\hline
\end{tabular}

55 adalah perempuan dengan mayoritas usia gestasi kurang bulan. Usia ibu terbanyak pada kelompok 2529 tahun, proporsi paritas hampir sama dan semua tanpa riwayat imunisasi rubela (Tabel 1 ).

Pada Tabel 2 terdapat hubungan bermakna $(\mathrm{p}<0,05)$ pada variabel jenis kelamin, usia gestasi, dan berat badan lahir dengan kasus probable SRK. Nilai median berat badan lahir kasus probable adalah 2500 gram. Berdasarkan nilai $\mathrm{p}<0,25$ maka variabel jenis kelamin, usia gestasi, dan berat badan dianalisis lebih lanjut dengan regresi logistik.

Berdasarkan hasil akhir analisis regresi logistik pada Tabel 3, secara statistik didapatkan hubungan bermakna jenis kelamin dan berat badan lahir dengan kasus probable SRK dengan tingkat akurasi $78,4 \%$. Usia gestasi tidak berhubungan dengan kasus probable SRK.

\section{Pembahasan}

Karakteristik utama subjek penelitian kami adalah jenis kelamin laki-laki, usia ibu 25-29 tahun, multipara, dan bayi merupakan klasifikasi kasus suspected SRK. Beberapa penelitian di Asia memiliki beberapa profil atau karakteristik yang sama. Penelitian di Filipina tahun 2005, subjek dominan adalah jenis kelamin pria dengan periode infant ( $<1$ tahun) saat manifestasi klinis SRK pertama kali diketahui. ${ }^{11}$ Penelitian di Iran dan Fiji dilaporkan predominan karakteristik jenis kelamin pria. ${ }^{12,13}$ Pada penelitian tersebut tidak memiliki subjek confirmed SRK.

Persentase klasifikasi kasus SRK adalah 72,2\% kasus suspected, 21,8\% kasus probable, dan 6\% confirmed SRK. Kondisi mayoritas suspected SRK juga terdapat pada penelitian beberapa negara berkembang yang belum memiliki sistem surveilans yang mapan. ${ }^{12-14}$ Pada kondisi tersebut penegakan diagnosis hanya berdasarkan manifestasi klinis karena tidak semua kasus suspected dan probable dilakukan pemeriksaan laboratorium untuk mengonfirmasi infeksi rubela kongenital, seperti yanag ditetapkan dalam sistem surveilans SRK oleh CDC tahun 2009. .,14,15 $^{-15}$

Terdapat hubungan kasus probable SRK dengan jenis kelamin. Penelitian terdahulu oleh PoethkoMuller dan Mankertz ${ }^{16}$ melaporkan hubungan signifikan laki-laki dengan seronegativitas antibodi rubela yang lebih tinggi, yang berarti kelompok laki- 
Lily Cahyani Tandililing dkk: Hubungan jenis kelamin, usia gestasi, dan berat badan lahir dengan SRK

Tabel 2. Hubungan jenis kelamin dan usia gestasi dengan kasus probable

\begin{tabular}{lccc}
\hline Variabel & \multicolumn{2}{c}{ Klasifikasi kasus } & \\
\cline { 2 - 3 } & $\begin{array}{c}\text { Suspected } \\
(\mathrm{n}=96)\end{array}$ & $\begin{array}{c}\text { Probable } \\
(\mathrm{n}=29)\end{array}$ & $p$ \\
\hline $\begin{array}{l}\text { Jenis kelamin } \\
\quad \text { Laki-laki }\end{array}$ & 48 & 25 & $0,001^{*}$ \\
$\quad \begin{array}{l}\text { Perempuan } \\
\text { Usia gestasi }\end{array}$ & 48 & 4 & \\
$\quad$ Kurang bulan & 51 & 20 & $0,131^{* *}$ \\
$\quad$ Cukup bulan & 45 & 9 & \\
$\begin{array}{l}\text { Berat badan lahir (gram) } \\
\text { Median } \\
\text { (minimum-maksimum) }\end{array}$ & 2.700 & 2.500 & \\
\hline
\end{tabular}

${ }^{*}$ chi-square test; ${ }^{* *} \mathrm{Uji}$ Eksak Fisher; ${ }^{* * *} \mathrm{Uji}$ Mann-Whitney; $\mathrm{p}=$ signifikansi $(\mathrm{p}<0,05)$;

Tabel 3. Regresi logistik hubungan jenis kelamin, usia gestasi, dan BBL dengan kasus probable

\begin{tabular}{lccc}
\hline Variabel & $\mathrm{p}$ & OR & $($ IK95\%) \\
\hline Jenis kelamin & 0,002 & 6,656 & $(2,046-21,657)$ \\
Berat badan lahir & $<0,001$ & 10,365 & $(2,839-37,843)$ \\
\hline p: signifikansi $<0,05$; OR: Odds rasio, signifikan bila $>2$; IK: Interval kepercayaan
\end{tabular}

laki lebih rentan dibanding dengan wanita. Riwayat pemberian imunisasi rubela terhadap subjek laki-laki pada penelitian tersebut lebih sedikit dibandingkan dengan perempuan. Subjek pada penelitian ini tidak memiliki riwayat pemberian imunisasi rubela. Virulensi virus rubela ditentukan oleh glikoprotein E1 dan E2 pada selubung virus. Glikoprotein E1 adalah bagian predominan untuk proses netralisasi virus. ${ }^{4}$ Pada penelitian Mitchell $\mathrm{dkk}^{7}$, subjek berjenis kelamin wanita lebih sedikit mendapatkan imunisasi rubela dibanding dengan laki-laki, terdapat onset pembentukan antibodi IgG dan IgM E1 yang lebih lambat disertai proporsi total antibodi terhadap protein E1 yang lebih kecil. Hal tersebut menjadikan wanita lebih rentan terhadap SRK. ${ }^{7}$

Berat badan lahir berhubungan dengan kasus probable SRK dengan median berat badan lahir 2500 gram. Berat badan lahir rendah sering dijumpai pada kasus SRK. Kondisi tersebut diakibatkan disfungsi plasenta dan insufisiensi vaskular akibat infeksi rubela. Kondisi patologis plasenta yang terjadi berupa hipoplasia, edema, dan nekrosis. ${ }^{9}, 10$ Penelitian terdahulu oleh Lejarraga dan Peckham ${ }^{8}$ melaporkan hubungan signifikan berat badan lahir dengan SRK, tetapi dengan subjek yang berbeda. Selain itu, penelitian tersebut dilakukan prospektif dengan menimbang langsung bayi, sedangkan penelitian kami hanya berdasarkan keterangan yang tertuang dalam anamnesis riwayat lahir subjek.

Usia gestasi dengan kasus probable SRK tidak berhubungan. Bayi dengan SRK dapat memiliki manifestasi klinis lahir prematur. ${ }^{4,17}$ Sama halnya dengan berat badan lahir rendah pada SRK, demikian pula kondisi patologis yang mendasari kelahiran prematur pada bayi dengan SRK. ${ }^{9,18}$ Sebuah laporan survei di Kanada oleh Munroe dkk ${ }^{19}$ dilaporkan 20\% kasus confirmed SRK dengan prematuritas dan berat badan lahir lahir rendah. Perbedaan hasil tersebut kemungkinan disebabkan oleh data yang digunakan adalah data sekunder, serta bersifat kategorik. Dengan demikian, diperlukan penelitian prospektif untuk menentukan hubungan usia gestasi dengan kasus probable SRK.

Keterbatasan penelitian kami adalah data penelitian yang diambil dari rekam medik sehingga besar kemungkinan kasus SRK banyak yang terlewatkan karena tidak semua pasien SRK memiliki manifestasi klinis yang khas. 
Lily Cahyani Tandililing dkk: Hubungan jenis kelamin, usia gestasi, dan berat badan lahir dengan SRK

\section{Kesimpulan}

Faktor jenis kelamin dan berat badan lahir memiliki hubungan dengan kasus probable sindrom rubela kongenital, tetapi masih diperlukan penelitian prospektif untuk menentukan hubungan usia gestasi dengan kasus probable sindrom rubela kongenital.

\section{Daftar pustaka}

1. Lambert N, Strebel P, Orenstein W, Icenogle J, Poland GA. Rubella. The Lancet 2015;14:1-11.

2. Robertson SE, Featherstone DA, Gacic-Dobo M, Hersh BS. Rubella and congenital rubella syndrome: global update. Rev Panam Slud Publica 2003;14(5):306-15.

3. Kementrian Kesehatan RI. Draft pedoman surveilans congenital rubella syndrome (CRS). Jakarta; Kementrian Kesehatan;2015.

4. Cherry JD, Adachi K. Rubella virus. Edisi ke-7. Dalam: Cherry JD, Harrison GJ, Kaplan SL, Steinbach WJ, Hotez PJ, penyunting. Philadelphia: Elsevier Saunders;2014.h.2193-325.

5. Thorburn MJ, Miller CG. Pathology of congenital rubella in Jamaica. Arch Dis Child. 1967;42:389-96.

6. McLean H, Reed S, Abernathy E, Icenogle J, Wallace G. Congenital rubella syndrome. Dalam: Roush SW, Baldy LM, penyunting. Manual for the surveillance of vaccine-preventable diseases. Atlanta: Centers for Disease Control and Prevention;2012.h.1-7.

7. Mitchell LA, Zhang T, Tingle AJ. Differential antibody response to rubella virus infection in males and females. J Infect Dis 1992;166:1258-65.

8. Lejarraga H, Peckham CS. Birthweight and subsequent growth of children exposed to rubella infection in utero. Arch Dis Child 1974;49:50-4.
9. Ornoy A, Segal S, Nishmi M, Simcha A, Polishuk WZ. Fetal and placental pathology in gestational rubella. Am J Obstet Gynecol 1973;116:949-56.

10. Webster WS. Teratogen update: congenital rubella. Teratology 1998;58:13-23.

11. Agnas CL. The analysis of clinical and social profile of congenital rubella syndrome seen among UP-PGH patients from the years 1993-2002 (A 10 year prevalence review). PIDSP J 2005;9:51-6.

12. Sadighi J, Eftekhar H, Mohammad K. Congenital rubella syndrome in Iran. BMC Infect Dis 2005;5:1-7.

13. Singh S, Bingwor F, Tayler-Smith K, Manzi M, Marks GB. Congenital rubella syndrome in Fiji. J Trop Med 2013:2013;1-5.

14. George IO, Frank-Briggs AI, Oruamabo RS. Congenital rubella syndrome: pattern and presentation in a southern Nigerian tertiary hospital. World J Pediatr 2009;5:1-5.

15. Orenstein WA, Preblud SR, Bart KJ, Hinman AR. Methods of assessing the impact of congenital rubella infection. Rev Infect Dis 1985;7(suppl.1):s22-8.

16. Poethko-Muller C, Mankertz A. Seroprevalence of measles, mumps, and rubella specific IgA antibodies in German children and adolescents and predictor for seronegativity Plos One 2012;7:1-13.

17. Ueda K, Hisanaga S, Nishida Y, Shepard TH. Lowbirth-weight and congenital rubella syndrome: effect of gestational age at time of maternal rubella infection. Clin Pediatr (Phila) 1981;20:730-3.

18. Peckham CS. Clinical and laboratory study of children exposed in utero to maternal rubella. Arch Dis Child1972;47:571-7.

19. Munroe S, Proll C, Brintnell J, Southall C, Mamer L. A survey of late emerging manifestation of congenital rubella in Canada. Canada: Canadian Deafblind and Rubella association; 1999. 